\title{
ANALISIS APLIKASI GF-AKUNTANSI DALAM SEGI KEAMANAN MENGGUNAKAN ISO/IEC 17799
}

\author{
Hendro $^{1}$, Ilivia ${ }^{2}$, Jajang Nurjaman ${ }^{3}$ \\ 1,2,3 Jurusan Teknik Informatika STT Indonesia Tanjungpinang \\ Jln. Pompa Air No. 28 Tanjungpinang Kepulauan Riau Indonesia \\ 1'quank_hwa@gmail.com \\ 2iliviaphang@gmail.com \\ 3a2ng2509@gmail.com
}

Intisari- Masalah keamanan merupakan salah satu aspek terpenting pada sebuah aplikasi. Masalah keamanan sering kali kurang mendapatkan perhatian dari para perancang dan pengelola aplikasi. Apabila menggangu performa aplikasi, sering kali masalah keamanan tidak begitu dipedulikan bahkan ditiadakan. PT Sukses Bintan Permata Kota Tanjungpinang sebuah perusahaan bergerak dibidang distributor makanan dan bahan pokok. Tujuan penelitian ini adalah untuk mengetahui tingkat keamanan pada aplikasi GF-Akuntansi, yang digunakan oleh PT. Sukses Bintan Permata kota Tanjungpinang.

ISO/IEC 17799 diterbitkan oleh International Organization for Standardizations (ISO) dan International Electrotechnical Commission (IEC), merupakan kode praktek untuk menyediakan suatu kerangka sebagai standar keamanan informasi. ISO/IEC 17799 sebagai metode penelitian ini, dengan menggunakan komponen Security policy, Physical and environmental security, Communications and Operations Management, dan Access Control.

Hasil penelitian menyatakan bahwa keamanan aplikasi GF-Akuntansi dalam setiap komponen dinyatakan baik, yang dapat dilihat rata-rata dari analisis keamanan GF-Akuntansi ini, semua komponen rata-rata mencapai nilai 75,5\% atau kriteria level fair/baik, seperti Security Policy telah mencapai nilai tertinggi yaitu 87\%. kemudian yang Physical and Enviromental Security dengan nilai $\mathbf{7 2 , 5 \%}$, Communication and Operation management dengan nilai $75 \%$ dan Access control dengan nilai $\mathbf{6 7 \%}$.

Kata kunci- Aplikasi, GF-Akuntansi, keamanan, ISO/IEC 17799

Abstract - Security issues are one of the most important aspects of an application. Security issues often get less attention from application designers and managers. If it interferes with application performance, security issues are often ignored or even eliminated. PT Sukses Bintan Permata Kota Tanjungpinang is a company engaged in the field of work. distributor of food and staples. The purpose of this study is to determine the level of security in the GF-Accounting application, which is used by PT. The success of Bintan Permata, the city of Tanjungpinang.

ISO / IEC 17799 published by the International Organization for Standardizations (ISO) and the International Electrotechnical Commission (IEC), is a code of practice to provide a framework as an information security standard. ISO / IEC 17799 as a method of this research, using the Security policy component, Physical and environmental security, Communications and Operations Management, and Access Control.

The results of the study state that the security of the GF-Accounting application in each component is declared good, which can be seen on average from this GF-Accounting security analysis, all components average a value of $75.5 \%$ or a fair / good level criterion, such as Security Policy. has reached the highest value, namely $87 \%$. then Physical and Environmental Security with a value of $72.5 \%$, Communication and Operation management with a value of $75 \%$ and Access control with a value of $67 \%$.

Keywords - Applications, GF-Accounting, security, ISO / IEC 17799 


\section{Pendahuluan}

Di tengah era globalisasi di mana perkembangan teknologi dan informasi berkembang dengan pesat, Peranan komputer sekarang ini sangat penting dalam pengolahan informasi, karena dengan pengolahan informasi yang berbasis komputer akan mampu menghasilkan informasi yang tepat, akurat, dan bermanfaat bagi suatu organisasi atau perusahaan. Perusahaan- perusahaan baik yang berskala besar maupun kecil harus cepat menanggapi perkembangan ini, penerapan teknologi dapat membantu meningkatkan efisiensi dan efektivitas perusahaan dalam segala bidang salah satunya dalam pencatatan akuntasi atau keuangan perusahaan, termasuk juga hal penjualan, pembelian dan juga hutang piutang perusahaan. Setiap perusahaan pasti adanya pencatatan pelaporan keuangan dan transaksi pembelian serta penjualan untuk kebutuhan perusahaan ataupun untuk dijual kembali.

GF-Akuntasi merupakan salah satu aplikasi akuntansi yang di resmikan oleh PT.GFsoft dan menawarkan program yang dapat diatur tampilan dan sistem kerjanya sesuai dengan jenis usaha yang dijalankan, mulai dari supplier, distributor, toko, café, dll.

PT. Sukses Bintan Permata Tanjungpinang merupakan perusahaan swasta yang bergerak di bidang distributor bahan pokok dan makanan ringan. Perusahaan tersebut menggunakan aplikasi GF-Akuntansi untuk pencatatan pelaporan keuangan serta transaksi-transaksi yang berhubungan dengan laporan keuangan seperti transaksi penerimaan kas, pengeluaran kas, penjualan, pembelian dll, karena data yang diolah merupakan data penting dan sampai saat ini belum belum dilakukan bentuk perencanaan evaluasi secara keseluruhan maupun konsep di dalam evaluasi keamanan apliasiGF-Akuntansidengan standar. Ancaman yang ditimbulkan dari kegiatan pengelolaan dan pemeliharaan aplikasi menjadi alasan perlunya penilaian tingkat efektivitas penerapan keamanan aplikasi, karena keamanan sistem informasi merupakan hal yang sangat penting bagi kelangsungan perusahaan, sehingga dapat dikatakan aplikasi adalah aset bagi perusahaan. Keamanan aplikasi secara langsung maupun tidak langsung dapat mempertahankan keberlangsungan proses bisnis bahkan memberikan peluang bisnis semakin besar.

Masalah keamanan merupakan salah satu aspek terpenting pada sebuah aplikasi.Masalah keamanan sering kali kurang mendapatkan perhatian dari para perancang dan pengelola aplikasi.Apabila menggangu performa aplikasi, sering kali masalah keamanan tidak begitu dipedulikan bahkan ditiadakan.Keunggulan sebuah aplikasi memiliki banyak keuntungan dalam kehidupan manusia.Akan tetapi, aspek negatifnya juga banyak terjadi, seperti kejahatan komputer, yang meliputi pencurian, penipuan, pemerasan, kompetitif, dan banyak lagi yang lainnya. Jatuhnya informasi ke tangan pihak lain (misalnya pihak lawan bisnis) dapat menimbulkan kerugian bagi pemilik informasi.

ISO/IEC 17799 diterbitkan oleh International Organization for Standardizations (ISO) dan International Electrotechnical Commission (IEC), merupakan kode praktek untuk menyediakan suatu kerangka sebagai standar keamanan informasi. Ini berarti menyediakan suatu tingkatan yang tinggi, deskripsi umum mengenai area yang seharusnya dipertimbangkan ketika mulai menerapkan, pelaksanaan atau memelihara keamanan informasi di manajemen.ISO/IEC 17799 memberikan secara komprehensif alat pengendalian berisikan praktek terbaik dalam keamanan informasi.Standar ini sekarang belum meliputi seluruh area yang penting namun masih mengalami revisi yang seksama.

Dari pembahasan diatas, penulis ingin melakukan penelitian terhadap aplikasi akuntansi GF-Akuntansi dengan mengujikan keamanan dengan metode ISO/IEC 17799.Oleh sebab itu, penulis mencoba membahas perbandingan kedua program tersebut dengan Judul skripsi "ANALISIS APLIKASI GF-AKUNTANSI DALAM SEGI KEAMANAN MENGGUNAKAN ISO/IEC 17799”.

\section{Metodologi Penelitian}

\subsection{Rancangan Penelitian}

Dalam melakukan penelitian ini,penulis memiliki rancangan penelitian guna memudahkan penulis dan berjalan sesuai yang diharapkan. Adapun rancangan penelitiannya antara lain sebagai berikut.

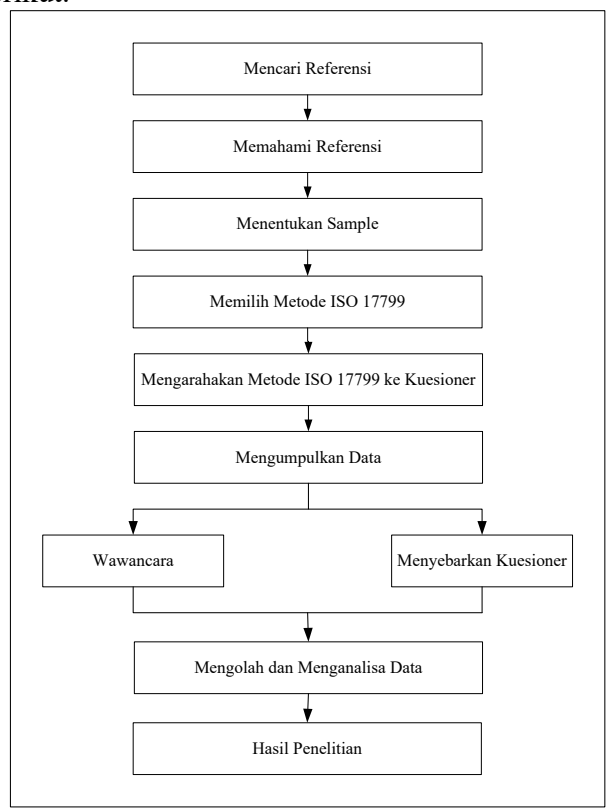

Gambar 3.1 Rancangan Penelitian

1. Tahap awal yang akan penulis lakukan adalah mencari refenrensi yang penulis fahami dan kuasai. Mencari Referensi penelitian ini bisa dilakukan dengan cara membaca penelitian yang sudah ada,seperti Jurnal dan E-book.

2. Setelah mencari referensi, tahap selanjutnya adalah memahami referensi yang telah di baca dari berbagai jurnal dan e-book. Pemahaman ini perlu dilakukan supaya penulis mengetahui dan memahami langkah apa yang akan diambil selanjutnya.

3. Langkah selanjutnya adalah menentukan sample dari user aplikasi GF-Akuntansi yang memenuhi criteria dari pemilihan sample.

4. Setelah menentukan sample, penulis akan membuat daftar pertanyaan untuk wawamcara dan juga daftar kuesioner untuk di berikan kepada user aplikasi GF-akuntansi yang 
berada di PT. Sukses Bintan Permata, selanjutnya data akan dikumpulkan dengan melakukan wawancara kepada kabag admin di PT. Sukses Bintan Permata yang mengunakan aplikasi GF-Akuntansi serta menyebarkan kuesioner kepada user aplikasi GF-Akuntansi yang merupakan sample dari penelitian

5. Setelah pengumpulan data dilakukan, maka data akan diolah dan dianalisis sesuai dengan metode ISO/IEC 17799 untuk perhitungan tingkat kapabilitas dan skala penilaian.

6. Tahap akhir dari penelitian ini adalah menghasilkan output berupa tingkat kematangan dari GF-Akuntansi sesuai dengan metodeISO/IEC 17799.

\subsection{Metode Pengumpulan Data}

Metode Pengumpulan data yang digunakan ialah dengan studi pustaka dan studi lapangan yang terbagi menjadi wawancara, observasi dan survei.

1. Studi Pustaka

Studi pustaka dilakukan dengan cara mempelajari teori-teori tentang ISO/IEC 17799 sebagai metode yang di terapkan dalam penelitian ini, cara mengumpulkan data beserta pengoperasian yang ada pada aplikasi GF-Akuntansi. Teori - teori tersebut diperoleh dari berbagai sumber seperti buku, jurnal, laporan penelitian, dan juga situs-situs di internet.

2. Studi Lapangan

Studi lapangan dilakukan dengan cara melibatkan user aplikasi GF-Akuntansi secara langsung. Hal ini berfungsi untuk mendapatkan informasi-informasi untuk mengumpulkan data dan keterangan yang berhubungan dengan permasalahan yang diteliti. Studi lapangan terdiri dari beberapa bagian:

3. Wawancara

Wawancara yaitu cara pengumpulan data dengan cara Tanya jawab dengan kabag Admin yang mengerti segala tentang pengoperasian aplikasi GF-Akuntansi ini (Terlampir).

4. Observasi

Penulis akan melakukan observasi secara langsung pada aplikasi GF-akuntansi pada saat dipakai oleh perusahaan.

5. Kuesioner

Menyebarkan suatu daftar yang berisi pertanyaan-pertanyaan yang harus diisi oleh useraplikasi GF-Akuntansi.Kuesiner ini digunakan untuk mengetahui tanggapan responden terhadap pertanyaan yang diajukan mengenai aplikasi GF-Akuntansi ini. Dalam hal ini kuesioner akan disebarkan oleh karyawan perusahaan PT. Sukses Bintan Permata bagian Admin.

Pada penenlitian ini digunakan kuisioner dangan skala guttman. Skala Guttman adalah skala pengukuran yang membutuhkan jawab tegas dari respondennya, seperti jawaban "ya" atau "tidak", "bener" atau "salah", "pernah" atau "tidak pernah" dan lain sebagainya[4]. Dalam menjawab skala guttman ini, responden hanya memberi tanda,misalnya checklist pada salah satu yaitu Ya atau Tidak. Jawaban tersebut diajukan untuk mendapatkan jawaban tegas oleh peneliti terkait permasahan yang ditanyakan.Untuk kebutuhan analisis data secara statistik dibutuhkan pemberian skor kepada jawaban tersebut, yang mana skor untuk jawaban yang mendukung atau jawabana positif (Ya dan yakin) diberi skor 1, dan skor untuk jawaban yang tidak mendukung atau negatif (tidak dan tidak yakin) diberi skor 0.Berikut adalah bobot penilaian pada skala guttman.

TABEL 1

BOBOT PENILAIAN

\begin{tabular}{|c|c|}
\hline JAWABAN & SKOR POSITIF \\
\hline YA & 1 \\
\hline TIDAK & 0 \\
\hline
\end{tabular}

Pengukuran analisis tingkat resiko di organisasi dilakukan pengukuran terhadap scoringdari kuesioner self assessment ISO/IEC 17799 sebanyak 40 pertanyaan dengan pilihan jawaban "Ya" dan "Tidak".Untuk pertanyaan yang dijawab "Ya" mendapatkan nilai 1 dan jawaban "Tidak" mendapatkan 0 . Total pertanyaan yang dijawab dengan "Ya" akan teridentifikasi sebagai tingkat pengelolaan resiko pada organisasi dengan klasifikasi sebagai berikut [5]:

TABEL 2

KRITERIA PENILAIAN KEMANAN SISTEM INFORMASI

\begin{tabular}{lcc}
\hline \multicolumn{1}{c}{ KATEGORI } & $\begin{array}{c}\text { SKOR } \\
\text { JAWABAN }\end{array}$ & $\begin{array}{c}\text { PERSENTASI } \\
\text { KEAMANAN }\end{array}$ \\
\hline "YEVEL & $>31$ & $>77 \%$ \\
SUPERIOR/BAIK & & \\
SEKALI & $28-31$ & $70 \%-77 \%$ \\
LEVEL FAIR/BAIK & $23-27$ & $58 \%-69 \%$ \\
LEVEL & $18-22$ & $45 \%-57 \%$ \\
MARGINAL/CUKUP & & $<45 \%$ \\
LEVEL & $<18$ & \\
POOR/KURANG & & \\
LEVEL $\boldsymbol{A T}$ RISK/BERESIKO [6] & & \\
& & \\
\hline
\end{tabular}

\section{HASIL DAN PEMBAHASAN}

\section{A. Analisis Deskriptif}

Deskriptif digunakan dengan menyusun table frekuensi distribusi untuk mengetahui apakah tingkat perolehan nilai variable penelitian masuk dalam kategori: Ya atau Tidak. Selanjutnya untuk menetapkan peringkat dalam setiap variable penelitian dapat dilihat dari perbandingan antara skor actual dengan skor ideal, skor actual diperoleh melalui hasil perhitungan seluruh pendapat responden sesuai klasifikasi bobot yang diberikan $(1,0)$, sedangkan skor ideal diperoleh melalui perolehan prediksi nilai tertinggi di kali dengan jumlah kuesioner dikalikan jumlah responden.

\section{Deskriptif Hasil Penelitian Variabel Security Policy}

$$
\% \text { Skor Aktual }=\frac{\text { Skor Aktual }}{\text { Skor } \text { ideal }} * 100 \%
$$

TABEL 2

HASIL PENELITIAN VARIABEL SECURITY POLICY

\begin{tabular}{l|lcccc}
\hline NO & \multicolumn{1}{c}{ PERTANYAAN } & YA & TIDAK & $\begin{array}{c}\text { SKOR } \\
\text { IDEAL }\end{array}$ & $\begin{array}{c}\text { SKOR } \\
\text { AKTUAL }\end{array}$ \\
\hline 1 & $\begin{array}{l}\text { Apakah ada kebijakan } \\
\text { keamanan informasi, yang } \\
\text { disetujui oleh manajemen, } \\
\text { diterbitkan dan } \\
\text { dikomunikasikan yang }\end{array}$ & 16 & 0 & 16 & 16 \\
& $\begin{array}{l}\text { sesuai untuk semua } \\
\text { karyawan. } \\
\text { Apakah kebijakan } \\
\text { menyatakan komitmen } \\
\text { manajemen dan } \\
\text { menetapkan organisasi } \\
\text { pendekatan untuk } \\
\text { mengelola keamanan }\end{array}$ & 14 & 2 & 16 & 4 \\
& & & & \\
& & & & \\
& & & & \\
\end{tabular}




\begin{tabular}{|c|c|c|c|c|c|}
\hline & informasi. & & & & \\
\hline 3 & $\begin{array}{l}\text { Apakah kebijakan } \\
\text { keamanan informasi } \\
\text { ditinjau pada interval yang } \\
\text { direncanakan, atau jika } \\
\text { perubahan signifikan } \\
\text { terjadi untuk memastikan } \\
\text { kesesuaian yang } \\
\text { berkelanjutan,kecukupan } \\
\text { dan efektivitas. }\end{array}$ & 14 & 2 & 16 & 14 \\
\hline 4 & $\begin{array}{l}\text { Apakah kebijakan } \\
\text { keamanan informasi } \\
\text { memiliki pemilik, yang } \\
\text { telah disetujui tanggung } \\
\text { jawab manajemen untuk } \\
\text { pengembangan, kajian dan } \\
\text { evaluasi kebijakan } \\
\text { keamanan }\end{array}$ & 12 & 4 & 16 & 12 \\
\hline \multirow[t]{2}{*}{5} & $\begin{array}{l}\text { Apakah prosedur review } \\
\text { informasi kebijakan } \\
\text { keamanan didefinisikan } \\
\text { ada dan melakukan mereka } \\
\text { termasuk persyaratan untuk } \\
\text { meninjau manajemen. }\end{array}$ & 12 & 2 & 16 & 14 \\
\hline & Total & 70 & 10 & 80 & 70 \\
\hline
\end{tabular}

Pada variable komponen Sucurity policy yang ditujukan pada table 4.5 disimpulkan dari 16 sampel yang diteliti dengan 5 pertanyaan yang diisikan oleh responden memperoleh total skor aktual 70 Poin, maka di peroleh kriteria berikut ini:

$$
\begin{aligned}
\% \text { Skor Aktual } & =\frac{\text { Skor Aktual }}{\text { Skor ideal }} * 100 \% \\
& =\frac{70}{80} * 100 \% \\
& =87.5 \%
\end{aligned}
$$

Ket : Level Superior/Baik Sekali

2. Deskriptif Hasil Penelitian Variabel Physical and Environmental Security

TABEL 3

JAWABAN VARIABEL PHYSICAL AND ENVIROMENTAL SECURITY

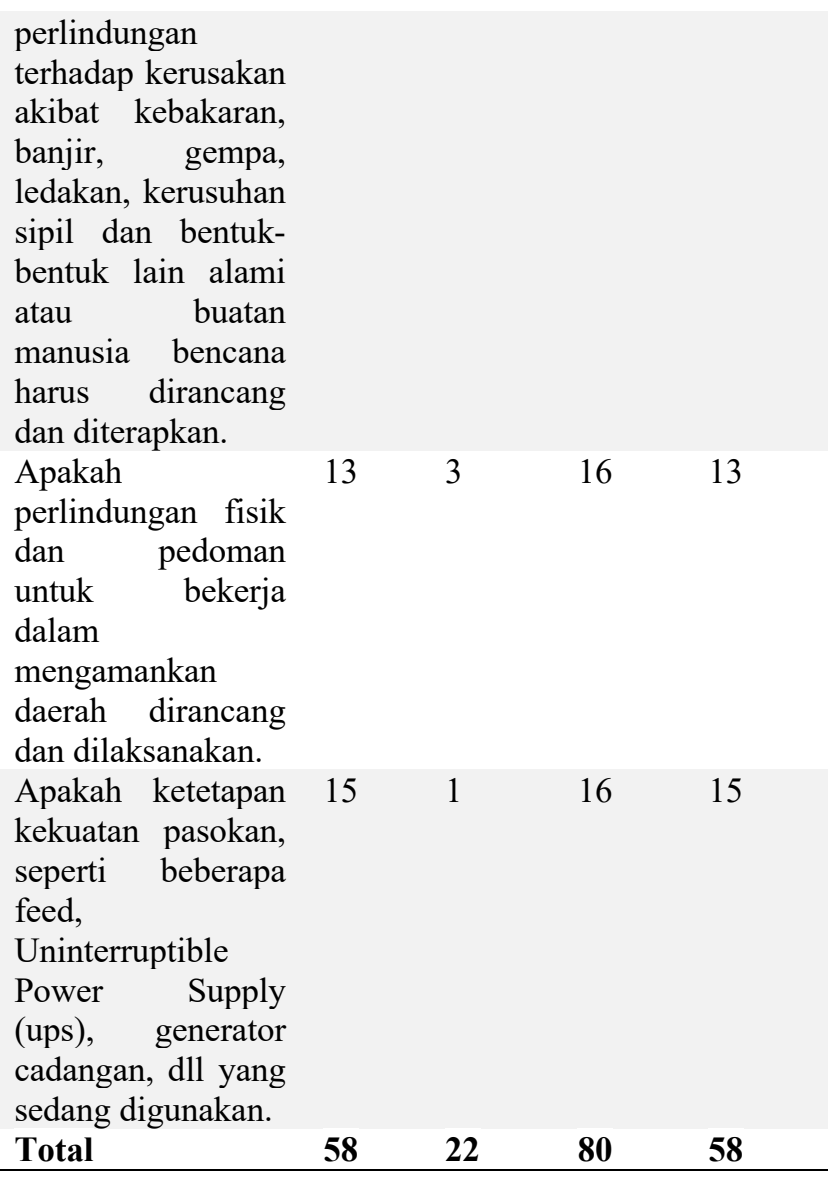

Pada variable komponen Physical and Environmental Security yang ditujukan pada table 4.6 disimpulkan dari 16 sampel yang diteliti dengan 5 pertanyaan yang diisikan oleh responden memperoleh total skor aktual 58 Poin, maka di peroleh Kriteria berikut ini:

$$
\begin{aligned}
\% \text { Skor Aktual } & =\frac{\text { Skor Aktual }}{\text { Skor ideal }} * 100 \% \\
& =\frac{58}{80} * 100 \%
\end{aligned}
$$$$
=72,5 \% \text { (Level Fair } / \text { Baik) }
$$

3. Deskriptif Hasil Penelitian Variabel Communications and Operations Management

TABEL 4

JAWABAN VARIABEL COMMUNICATION AND OPERATIONS MANAGEMENT

\begin{tabular}{l|lllll}
$\mathbf{N O}$ & PETANYAAN & YA & TIDAK & $\begin{array}{l}\text { SKOR } \\
\text { IDEAL }\end{array}$ & $\begin{array}{l}\text { SKOR } \\
\text { AKTUAL }\end{array}$ \\
\hline $\mathbf{1}$ & $\begin{array}{l}\text { Apakah prosedur } \\
\text { operasi } \\
\text { didokumentasikan, } \\
\text { terawat dan tersedia } \\
\text { untuk semua pengguna } \\
\text { yang membutuhkannya. } \\
\text { Apakah semua } \\
\text { perubahan pengolahan } \\
\text { fasilitas dan sistem } \\
\text { informasi dikendalikan. } \\
\text { Apakah tugas dan }\end{array}$ & 8 & 8 & 16 & 8 \\
\hline
\end{tabular}




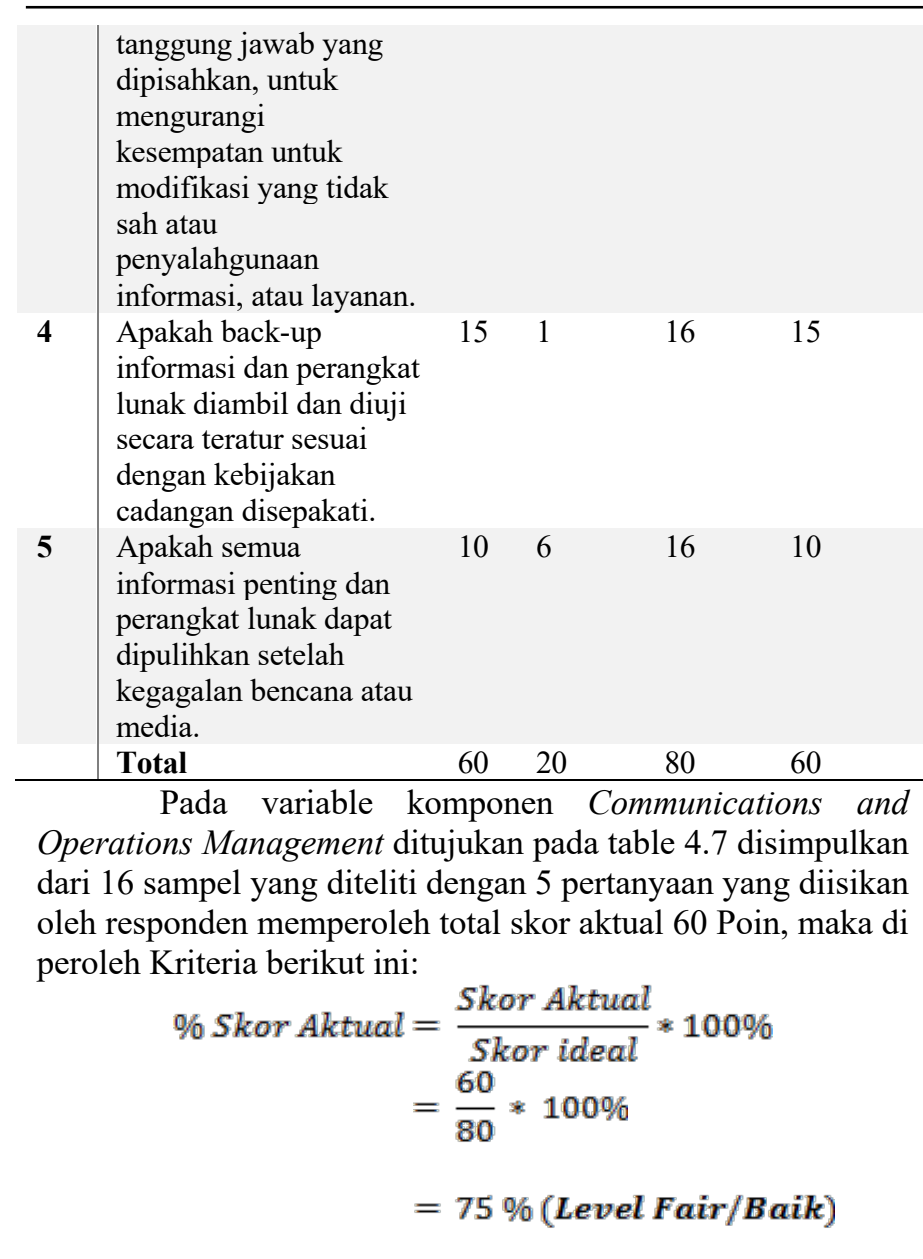

4. Deskriptif Hasil Penelitian Variabel Access Control

TABEL 5

JAWABAN VARIABEL ACCESS CONTROL

\begin{tabular}{|c|c|c|c|c|c|}
\hline No & PETANYAAN & YA & TIDAK & $\begin{array}{c}\text { SKOR } \\
\text { IDEAL }\end{array}$ & $\begin{array}{c}\text { SKOR } \\
\text { AKTUAL }\end{array}$ \\
\hline 1 & $\begin{array}{l}\text { Apakah kebijakan } \\
\text { kontrol akses } \\
\text { dikembangkan dan } \\
\text { ditinjau berdasarkan } \\
\text { persyaratan bisnis } \\
\text { dan keamanan. }\end{array}$ & 8 & 8 & 16 & 8 \\
\hline 2 & $\begin{array}{l}\text { Apakah kontrol akses } \\
\text { yang logis dan fisik } \\
\text { harus } \\
\text { dipertimbangkan } \\
\text { dalam kebijakan }\end{array}$ & 13 & 3 & 16 & 13 \\
\hline 3 & $\begin{array}{l}\text { Apakah pengguna } \\
\text { dan penyedia layanan } \\
\text { diberikan pernyataan } \\
\text { yang jelas mengenai } \\
\text { kebutuhan bisnis } \\
\text { harus dipenuhi oleh } \\
\text { kontrol akses. }\end{array}$ & 15 & 1 & 16 & 15 \\
\hline 4 & $\begin{array}{l}\text { Apakah ada setiap } \\
\text { pendaftaran } \\
\text { pengguna resmi dan } \\
\text { de-pendaftaran } \\
\text { prosedur untuk }\end{array}$ & 6 & 10 & 16 & 6 \\
\hline
\end{tabular}

memberikan akses ke

semua sistem

informasi dan

layanan.

Apakah ada setiap

praktek keamanan di tempat untuk

memandu pengguna

dalam memilih dan

mempertahankan

password yang aman.

6 Apakah alokasi dan

penggunaan setiap

hak dalam

lingkungan sistem

informasi terbatas

dan dikendalikan

yaitu, keistimewaan

dilokasikan secara

perlu digunakan,

keistimewaan

dialokasikan hanya

setelah proses formal

atorisasi

Apakah pengguna

disediakan dengan

akses hanya untuk

layanan bahwa

mereka telah secara

khusus diizinkan

untuk menggunakan.

8

Apakah ada

kebijakan yang

alamat keprihatinan

berkaitan dengan

jaringan dan layanan jaringan.

Apakah mekanisme

otentikasi yang

sesuai digunakan

untuk mengontrol

akses oleh pengguna

jarak jauh.

10 Apakah fisik dan

logis akses ke

pelabuhan diagnostik

aman dikontrol yaitu,

dilindungi oleh

mekanisme

keamanan.

11

Apakah ada

kebijakan kontrol

akses yang

menyatakan kontrol

koneksi jaringan

untuk jaringan

bersama, terutama

bagi meluas melintasi

batas-batas

organisasi.
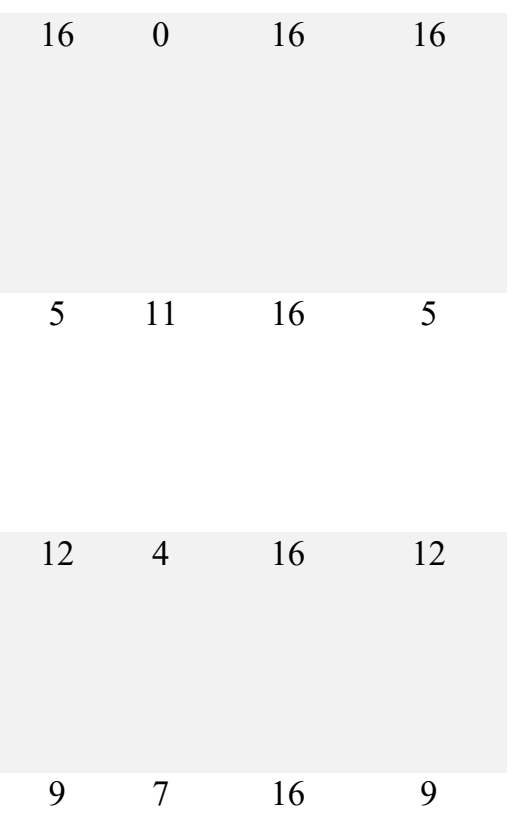


$12 \begin{array}{lllll}\text { Apakah } & 11 & 5 & 16 & 11 \\ \text { pengidentifikasi unik } & & & & \\ \text { (user ID) disediakan } & & & & \\ \text { untuk setiap } & & & & \\ \text { pengguna seperti } & & & & \\ \text { operator, sistem } \\ \text { administrator dan staf } \\ \text { lainnya termasuk } \\ \text { teknis. }\end{array}$

Pada variable komponen Access Control ditujukan pada table 4.8 disimpulkan dari 16 sampel yang diteliti dengan 15 pertanyaan yang diisikan oleh responden memperoleh total skor aktual 161 Poin, maka di peroleh Kriteria berikut ini:

$$
\begin{aligned}
\% \text { Skor Aktual } & =\frac{\text { Skor Aktual }}{\text { Skor ideal }} * 100 \% \\
& =\frac{161}{240} * 100 \%
\end{aligned}
$$

\section{B. Pengujian}

Hasil Pengujian dari penelitian ini merupakan hasil dari pengolahan data yang diperoleh pada PT Sukses Bintan Permata kota Tanjungpinang ataupun hasil dari pengolahan data kuesioner yang telah disebarkan, adapun hasil dari penelitian ini adalah sebagai berikut.

1. Pengujian Validitas

Berikut ini adalah hasil pengujian validitas untuk variable Security policy

TABEL 6

HASIL UJI VALIDITAS SECURITY POLICY

\begin{tabular}{c|lll}
$\begin{array}{c}\text { NO } \\
\text { SOAL }\end{array}$ & R HITUNG & \multicolumn{1}{c}{ R TABLE } & \multicolumn{1}{c}{ KETERANGAN } \\
\hline 1 & - & - & - \\
2 & 0,666 & 0,497 & Valid \\
3 & 0,666 & 0,497 & Valid \\
4 & 0,277 & 0,497 & Tidak Valid \\
5 & 0,666 & 0,497 & Valid \\
\hline
\end{tabular}

Berikut ini adalah hasil pengujian validitas untuk variable physical and environmental security

TABEL 7

\begin{tabular}{|c|c|c|c|}
\hline $\begin{array}{c}\text { NO } \\
\text { SOAL }\end{array}$ & R HITUNG & R TABLE & KETERANGAN \\
\hline 1 & 0,821 & 0,497 & Valid \\
\hline 2 & 0.715 & 0,497 & Valid \\
\hline 3 & 0.652 & 0,497 & Valid \\
\hline 4 & 0.378 & 0,497 & Tidak Valid \\
\hline 5 & 0.132 & 0,497 & Tidak Valid \\
\hline
\end{tabular}

HASIL UJI VALIDITAS PHYSICAL AND ENVIRONMENTAL SECURITY

Berikut ini adalah hasil pengujian validitas untuk variable Communications and Operations Management
TABEL 8

HASIL UJI VALIDITAS COMMUNICATIONS AND OPERATIONS MANAGEMENT

\begin{tabular}{c|ccc}
$\begin{array}{c}\text { NO } \\
\text { SOAL }\end{array}$ & R HITUNG & R TABLE & KETERANGAN \\
\hline 1 & 0,344 & 0,497 & Tidak Valid \\
2 & 0.652 & 0,497 & Valid \\
3 & 0.662 & 0,497 & Valid \\
4 & 0.415 & 0,497 & Tidak Valid \\
5 & 0.770 & 0,497 & Valid
\end{tabular}

Berikut ini adalah hasil pengujian validitas untuk variable Access Control

TABEL 9

HASIL UJI VALIDITAS ACCESS CONTROL

\begin{tabular}{c|lll}
$\begin{array}{c}\text { NO } \\
\text { SOAL }\end{array}$ & \multicolumn{1}{c}{ R HITUNG } & \multicolumn{1}{c}{ R TABLE } & \multicolumn{1}{c}{ KETERANGAN } \\
\hline 1 & 0.653 & 0,497 & Valid \\
2 & 0.658 & 0,497 & Valid \\
3 & 0.092 & 0,497 & Tidak Valid \\
4 & 0.723 & 0,497 & Valid \\
5 & 0.064 & 0,497 & Tidak Valid \\
6 & 0.559 & 0,497 & Valid \\
7 & - & 0,497 & - \\
8 & 0.713 & 0,497 & Valid \\
9 & 0.644 & 0,497 & Valid \\
10 & 0.443 & 0,497 & Tidak Valid \\
11 & 0.274 & 0,497 & Tidak Valid \\
12 & 0.287 & 0,497 & Tidak Valid \\
13 & 0.287 & 0,497 & Tidak Valid \\
14 & 0.658 & 0,497 & Valid \\
15 & 0.495 & 0,497 & Tidak Valid
\end{tabular}

2. Pengujian Realibilitas

Berikut ini adalah hasil pengujian Reliabilitas untuk variabel Security policy.

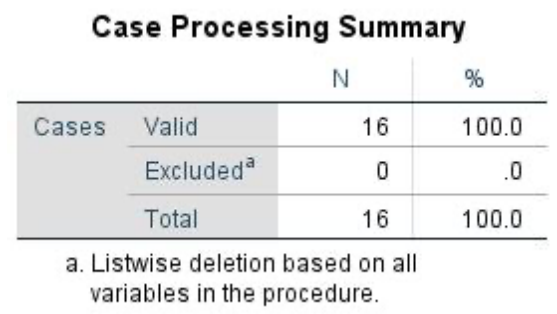

Reliability Statistics

\begin{tabular}{r|r}
$\begin{array}{c}\text { Cronbach's } \\
\text { Alpha }\end{array}$ & N of Items \\
\hline .646 & 6 \\
\hline
\end{tabular}

Sumber : IBM SPSS Version 24

Gambar 1 Output Reliabilitas Security Policy

Nilai koefisien Reliabilias untuk Security Policy menunjukan 0,646.Maka hasil data kuesioner memiliki tingkat reliabilitas yang baik, artinya data reabilitas dapat dipercaya. Berikut ini adalah hasil pengujian Reliabilitas untuk variabel physical and environmental security. 


\begin{tabular}{|c|c|c|c|}
\hline \multicolumn{4}{|c|}{ Case Processing Summary } \\
\hline & & $\mathrm{N}$ & $\%$ \\
\hline \multirow[t]{3}{*}{ Cases } & Valid & 16 & 100.0 \\
\hline & Excluded $^{\text {a }}$ & 0 & .0 \\
\hline & Total & 16 & 100.0 \\
\hline
\end{tabular}

variables in the procedure.

\section{Reliability Statistics}

\begin{tabular}{r|r}
$\begin{array}{c}\text { Cronbach's } \\
\text { Alpha }\end{array}$ & N of Items \\
\hline .722 & 6 \\
\hline
\end{tabular}

Sumber : IBM SPSS Version 24

Gambar 2 Output Reliabilitas physical and environmental security

Nilai koefisien Reliabiliasuntuk physical and environmental security menunjukan 0,722. Maka hasil data kuesioner memiliki tingkat reliabilitas yang baik, artinya data reabilitas dapat dipercaya. Berikut ini adalah hasil pengujian Reliabilitas untuk variabel Communications and Operations Management.

Case Processing Summary

\begin{tabular}{|c|c|c|c|}
\hline & & v & $\%$ \\
\hline \multirow[t]{3}{*}{ Cases } & Valid & 16 & 100.0 \\
\hline & Excluded $^{a}$ & 0 & .0 \\
\hline & Total & 16 & 100.0 \\
\hline
\end{tabular}

Reliability Statistics

\begin{tabular}{r|r}
$\begin{array}{c}\text { Cronbach's } \\
\text { Alpha }\end{array}$ & N of Items \\
\hline .701 & 6 \\
\hline
\end{tabular}

Sumber : IBM SPSS Version 24

Gambar 3 Output Reliabilitas Communications and Operations Management

Nilai koefisien Reliabiliasuntuk Communications and Operations Management menunjukan 0,701. Maka hasil data kuesioner memiliki tingkat reliabilitas yang baik, artinya data reabilitas dapat dipercaya. Berikut ini adalah hasil pengujian Reliabilitas untuk variabel Communications and Operations Management.

Case Processing Summary
\begin{tabular}{ll|r|r}
\multicolumn{1}{c}{} & \multicolumn{1}{c}{$\%$} \\
\hline \multirow{2}{*}{ Cases } & Valid & 16 & 100.0 \\
\cline { 2 - 4 } & Excluded $^{\mathrm{a}}$ & 0 & .0 \\
\cline { 2 - 4 } & Total $^{*}$ & 16 & 100.0 \\
\hline
\end{tabular}

a. Listwise deletion based on all variables in the procedure.

\begin{tabular}{|c|c|}
\hline \multicolumn{2}{|c|}{ Reliability Statistics } \\
\hline $\begin{array}{c}\text { Cronbach's } \\
\text { Alpha }\end{array}$ & $\mathrm{N}$ of Items \\
\hline .716 & 16 \\
\hline
\end{tabular}

Sumber : IBM SPSS Version 24

Gambar 4 Output Reliabilitas Access Control

Nilai koefisien Reliabiliasuntuk Access Control menunjukan 0,716. Maka hasil data kuesioner memiliki tingkat reliabilitas yang baik, artinya data reabilitas dapat dipercaya.

\section{KESIMPULAN}

Setelah melakukan analisis aplikasi GF-Akuntansi menggunakan ISO 17799 di PT Sukses Bintan Permata, Maka Penulis dapat menyimpulkan bahwa:

1. Security Policy atau kebijakan keamanan sebesar $87,5 \%$ dengan kriteria Superior.

2. physical and environmental security atau keamanan fisik dan lingkungan sebesar 72,5\% dengan Kriteria fair.

3. Communications and Operations Management atau Komunikasi dan manajemen operasi sebesar $75 \%$ dengan Kriteria fair.

4. Access Control atau Kontrol akses sebesar 67\% dengan Kriteria marginal.

5. Hipotesa berdasarkan penelitian ini pada aplikasi GFAkuntansi mengunakan metode ISO 17799, aman diterapkan pada perusahaan untuk mendukung proses bisnis.

6. Berdasarkan hasil uji validitas, pada komponen security policy terdapat 3 item pertanyaan yang valid, komponen physical and environmental security terdapat 3 item pertanyaan yang valid, komponen communication and operations management terdapat 3 pertanyaan valid, dan security policy terdapat 7 yang valid. Item pertanyaan tersebut valid karena $\mathrm{r}$ hitung $>\mathrm{r}$ table. $\mathrm{R}$ table peda penelitian ini adalah 0,497.

7. Berdasarkan hasil uji Reliabilitas, nilai Alpha Cronbach untuk komponen security policy sebesar 0,646, artinya hasil data kuesioner memiliki tingkat reliablitas yang baik atau dapat dipercaya, komponen physical and environmental security sebesar 0.722 artinya hasil data kuesioner memiliki tingkat reliabilitas yang baik atau dapat dipercaya, komponen communication and operation management sebesar 0,701, artinya hasil data kuesioner memiliki tingkat reliabilitas yang baik atau dapat dipercaya, dan komponen access control sebesar 0,716, artinya hasil data kuesioner memiliki tingkat raliabilitas yang baik atau dapat dipercaya

\section{REFERENSI}

[1] https://www.iso.org/standard/39612.html [2018, November 02 / 18:29]

[2] Sarmih. "Analisis Pengaruh Penggunaan Aplikasi GFAkuntansi Terhadap kinerja karyawan PT.Bangunan Indah Sejahtera Kota Tanjungpinang" (Skripsi), Tanjungpinang, STT Indonesia, 2017

[3] YulianaDian. "Analisis Efektivitas Aplikasi GF- 
Akuntansi Menggunakan Framework Cobit 5 Domain DSS (Deliver, Service and Support)" (Skripsi), Tanjungpinang, STT Indonesia, 2017

[4] https://www.spssstatistik.com/kuesioner-penelitiandengan-skala-guttman/ [2018, Desember 09 / 15:49]

[5] Meirlin, Indrastanti, Dian. "Audit Keamanan Informasi pada Labotarium computer Menggunakan ISO / IEC
17799 : 2005" (Artikel Imiah), Salatiga, Universitas Kristen Satya Wacana,2013

[6] Mona, Nurlaela. "Evaluasi Keamanan Sistem Informasi Akademik Menggunakan ISO 17799:2000” (Jurnal), papua, Universitas papua, 2016 